\title{
Diagnostic role of Wnt pathway gene promoter methylation in non small cell lung cancer
}

\author{
Shunlin Liu ${ }^{1, *}$, Xiaoying Chen ${ }^{2, *}$, Ruhua Chen ${ }^{3, *}$, Jinzhi Wang $^{4, *}$, Guoliang Zhu ${ }^{5}$, \\ Jianzhong Jiang ${ }^{6}$, Hongwei Wang ${ }^{7}$, Shiwei Duan ${ }^{2}$, Jianan Huang ${ }^{1}$ \\ ${ }^{1}$ Department of Respiratory Medicine, The First Affiliated Hospital of Soochow University, Suzhou, Jiangsu 215006, China \\ ${ }^{2}$ Medical Genetics Center, School of Medicine, Ningbo University, Ningbo, Zhejiang 315211, China \\ ${ }^{3}$ Department of Respiratory Medicine, Affiliated Yixing Hospital of Jiangsu University, Yixing, Jiangsu 214200, China \\ ${ }^{4}$ Department of Cell Biology, School of Medicine, Soochow University, Suzhou, Jiangsu 215007, China \\ ${ }^{5}$ Department of Pathology, Huzhou First People's Hospital, Huzhou, Zhejiang 313000, China \\ ${ }^{6}$ Department of Geriatrics, Affiliated Yixing Hospital of Jiangsu University, Yixing, Jiangsu 214200, China \\ ${ }^{7}$ Realgen Biotechnology Co., Ltd. Zhangjiang High Technology Park, Shanghai 201203, China \\ * Co-first authors
}

Correspondence to: Jianan Huang, email: huang_jian_an@163.com

Shiwei Duan, email: duanshiwei@nbu.edu.cn

Keywords: non-small cell lung cancer, quantitative methylation-specific PCR, DNA methylation, diagnosis, Wnt pathway

Received: November 22, 2016

Accepted: March 21, 2017

Published: March 31, 2017

Copyright: Liu et al. This is an open-access article distributed under the terms of the Creative Commons Attribution License (CC-BY), which permits unrestricted use, distribution, and reproduction in any medium, provided the original author and source are credited.

\section{ABSTRACT}

Wnt signal pathway genes are known to be involved with cancer development. Here we tested the hypothesis whether DNA methylation of genes part of the Wnt signaling pathway could help the diagnosis of non-small cell lung cancer (NSCLC). The methylation levels of SFRP1, SFRP2, WIF1 and PRKCB in 111 NSCLC patients were evaluated by quantitative methylation-specific PCR (qMSP). Promoter methylation levels of four candidate genes were significantly higher in tumor tissues compared with the adjacent tissues. SFRP1, SFRP2 and PRKCB genes were all shown to be good predictors of NSCLC risk (SFRP1: AUC $=0.711$; SFRP2: AUC $=0.631$; PRKCB: AUC = 0.650). The combined analysis showed that the methylation status of the four genes had a sensitivity of $70.3 \%$ and a specificity of $73.9 \%$ in the prediction of NSCLC risk for study cohort. A higher diagnostic value with an AUC of 0.945 (95\% CI: 0.923-0.967, sensitivity: $\mathbf{9 0 . 6 \%}$, specificity: $93.0 \%$ ) was found in TCGA cohort. In addition, SFRP1 and SFRP2 hypermethylation events were specific to male patients. Further TCGA data mining analysis suggested that SFRP1_cg15839448, SFRP2_cg05774801, and WIF1_ cg21383810 were inversely associated with the host gene expression. Moreover, GEO database analysis showed that 5'-Aza-deoxycytidine was able to upregulate gene expression in several lung cancer cell lines. Subsequent dual-luciferase reporter assay showed a crucial regulatory function of $P R K C B$ promoter. In summary, our study showed that a panel of Wnt signal pathway genes (SFRP1, SFRP2, WIF1 and PRKCB) had the potential as methylation biomarkers in the diagnosis of NSCLC.

\section{INTRODUCTION}

Lung cancer is the most common cancer and the leading cause of cancer death in China [1]. As a heterogeneous disease, lung cancer can be classified into small cell lung cancer and non-small cell lung cancer (NSCLC). NSCLC includes lung squamous carcinoma (LUSC), lung adenocarcinoma (LUAD) and large cell carcinoma [2]. Although the diagnosis and treatment of NSCLC have been improved in the recent years, its 5-year overall survival rate (OS) is still poor $(\sim 15 \%)$ [3].

DNA methylation is one of the most well-known epigenetic modifications. The cytosine of CG nucleotide in the DNA sequence is selectively added a methyl group [4]. Aberrant DNA methylation of $\mathrm{CpG}$ islands may lead to the transcriptional silencing of tumor suppressor genes 
[5]. Since DNA methylation is frequently altered in lung cancer [6], increasing number of highly sensitive assays have been developed to assess gene promoter methylation in biological fluids in order to non-invasively identify early cancer in the high risk population.

Wingless-type (Wnt) signal pathway components were reported to be markedly associated with the initiation and development of NSCLC [7]. Two functional classes of extracellular Wnt antagonists have been identified [8]. The secreted frizzled related protein (SFRP) family (SFRP1$S F R P 5)$ and Wnt inhibitory factor-1 (WIFl) proteins inhibit Wnt signaling by directly binding to Wnt molecules [8]. SFRP1 promoter methylation has been reported to contribute to the tumorigenesis and progression of many human cancers [9-13], including lung cancer [14]. SFRP2 and WIF 1 promoter methylation was previously suggested to play important roles in Wnt signaling in lung cancer $[15,16]$. Protein kinase $\mathrm{C}$ beta (PRKCB) belongs to PKC family members, which is involved in Wnt pathway [17]. $P R K C B$ was reported to be hypermethylated in lung adenocarcinoma stage I while hypomethylated in stage II [18], suggesting a potential of $P R K C B$ hypermethylation assessment for NSCLC early detection.

In the current study, we evaluated the association between the promoter methylation of four Wnt signaling pathway genes (SFRP1, SFRP2, WIF1 and PRKCB) and NSCLC risk. The goal of our study was to investigate whether they could be used as a panel of methylation biomarkers in the diagnosis of NSCLC risk.

\section{RESULTS}

\section{Methylation levels of SFRP1, SFRP2, PRKCB and WIF1 genes in NSCLC}

As illustrated in Figure 1A and 1D, the percentage of methylated reference (PMR) levels of SFRP1, SFRP2, $P R K C B$ and WIF1 in 111 NSCLC tumor tissues and 111 paired adjacent tissues were quantified by SYBR greenbased quantitative methylation-specific PCR (qMSP). The median (interquartile range) PMR levels of SFRP1, $S F R P 2, P R K C B$ and WIF1 in tumor tissues were $5.01 \%$ (2.32-15.82\%), 15.00\% (3.49-47.27\%), 13.89\% (6.89$24.57 \%)$ and $39.49 \%(22.21-76.05 \%)$, respectively, and in adjacent non-tumor tissues were $2.24 \%$ $(1.12-3.46 \%), \quad 7.17 \% \quad(1.86-16.62 \%), \quad 8.94 \%$ (4.30-15.17\%) and $34.66 \%$ (18.04-58.69\%), respectively. Our results showed that methylation levels of four genes in tumor tissues were significantly higher than that in the adjacent tissues (all $P<0.05$; Mann-Whitney test). Subgroup analysis by histological type showed that significantly higher methylation events of two (SFRPI and $S F R P 2$ ) and three genes (SFRP1, SFRP2 and PRKCB) were observed in LUSC and LUAD, respectively.

To assess DNA hypermethylation frequencies in our cohort and The Cancer Genome Atlas (TCGA) cohort, cut- off values for each gene were obtained from the quantile representing the upper $95 \%$ of methylation levels in nontumor samples $[19,20]$. Therefore, the percentages of hypermethylation for SFRP1, SFRP2, WIF1 and PRKCB were $25.2 \%$ (28/111), 7.2\% (8/111), 9.0\% (10/111) and $21.6 \%(24 / 111)$ with corresponding PMR cut-off values of $13.694,360.400,127.500$ and 27.494. In TCGA cohort, the percentages of hypermethylation for SFRP1, SFRP 2, WIF1 and PRKCB were 58.9\% (489/830), 67.2\% (558/830), 67.0\% (556/830) and 57.8\% (480/830) with $\beta$ cut-off values of $-0.408,-0.328,-0.406$ and -0.330 .

As shown in Table 1, no association was identified between $P R K C B$ or WIF1 methylation and gender, age, histological type, clinical stage, tumor location, differentiation and smoking behavior. However, increased $S F R P 1$ and SFRP2 methylation levels were more frequently detected in male NSCLC patients (SFRPI: $5.81 \%$ versus $3.06 \%, P=0.043 ; S F R P 2: 28.67 \%$ versus $8.38 \%, P=0.007$, respectively).

\section{Diagnostic values of SFRP1, SFRP2, PRKCB and WIF1 methylation in NSCLC}

As shown in Figure 2A, SFRP1, SFRP2 and PRKCB methylation levels could discriminate NSCLC tissues from adjacent non-tumor samples. Using a PMR cut-off value of 3.65, SFRP1 yielded a significant area under the curve (AUC) of 0.711 (95\% CI: $0.642-0.780$ ) with a sensitivity of $62.2 \%$ and a specificity of $77.5 \%$. Using a PMR cutoff value of 18.76, SFRP2 yielded a significant AUC of 0.631 (95\% CI: $0.557-0.704$ ) with a sensitivity of $47.7 \%$ and a specificity of $80.2 \%$. PRKCB yielded a significant AUC of 0.650 (95\% CI: $0.578-0.721)$ with a sensitivity of $59.5 \%$ and a specificity of $68.5 \%$ from a PMR cut-off value of 12.53 .

Although WIF1 methylation lacked in good predictive capability, a combined analysis of the four markers improved test accuracy with a sensitivity of $70.3 \%$ and a specificity of $73.9 \%$ with AUC of 0.747 (95\% CI: 0.683-0.811). As shown in Figure 2B and 2C, combined receiver operating characteristic (ROC) curve indicated that a good diagnostic value of four genes was found in both LUAD (an AUC of 0.798 with a sensitivity of $78.3 \%$ and a specificity of $72.5 \%$ ) and LUSC (an AUC of 0.728 with a sensitivity of $69.0 \%$ and a specificity of $71.4 \%)$.

Subsequently, we have used the TCGA cohort to confirm our findings. As shown in Figure 2D, a higher diagnostic value of the epigenetic panel among NSCLC patients has been found and the combination AUC of four genes was 0.932 (95\% CI: $0.914-0.950)$. The sensitivity and the specificity were $83.3 \%$ and $96.0 \%$, respectively. Likewise, the combined ROC curve in LUAD indicated a good diagnostic value with a significant AUC of 0.961 (95\% CI: $0.943-0.979$, sensitivity: $88.4 \%$, specificity: $96.7 \%$, Figure 2E). The combined ROC curve of LUSC 
also showed a similar value with an AUC of $0.945(95 \%$ CI: 0.923-0.967, sensitivity: $90.6 \%$, specificity: $93.0 \%$, Figure 2F).

\section{Survival analysis of NSCLC patients}

A total of 11 among 111 NSCLC patients were dead. A univariate analysis showed that disease stage and Response Evaluation Criteria In Solid Tumors (RECIST) tumor response evaluation were associated with a poor OS (Table 2, HR = 44.761, 95\% CI = 5.721-350.202; $\mathrm{HR}=108.952,95 \% \mathrm{CI}=13.796-860.410$, respectively) SFRP1 methylation was shown as a moderate factor of OS in the univariate analysis $(P=0.055)$, three factors were included in subsequent multivariate analysis. A further Cox regression analysis showed there was no association of SFRP1 methylation with the OS of NSCLC patients $(\mathrm{HR}=1.001,95 \% \mathrm{CI}=0.996-1.007)$.

\section{Correlation between DNA methylation and gene expression}

We also utilized the available methylation data and mRNA data from TCGA datasets (Figure 3). In 818 NSCLC patients, methylation levels of three genes were shown to be inversely correlated with gene expression (SFRP1_cg15839448: Spearman $\mathrm{r}=-0.367, P<0.001$, Figure 3A; SFRP2_cg05774801: Spearman r $=-0.095$, $P=0.007$, Figure 3C; WIF1_cg21383810: Spearman $\mathrm{r}=-0.263, P<0.001$, Figure 3D). It was intriguing that positive correlations were found between two $\mathrm{CpG}$ sites of PRKCB (cg24250393 and $\operatorname{cg} 08406370)$ and gene expression (Spearman $\mathrm{r}=0.152, P<0.001$, Figure 3E; Spearman $r=0.116, P=0.001$, Figure $3 \mathrm{~F}$, respectively), suggesting that there might be a complex epigenetic regulation in $P R K C B$ gene expression. No significant correlation was observed between SFRP2_cg05874561 methylation and its host gene expression $(P>0.05$, Figure 3B).

We further analyzed the gene expression data of 3 NSCLC cell lines (A549, H1993 and H2073) before and after 5-aza-2'-deoxycytidine (5-AZA) treatment (accession number GSE32496). We observed that the expression levels of SFRP1, SFRP2 and PRKCB gene in A549 were significantly elevated after demethylation $(P=0.017$, $P=0.043, P=0.008$, respectively; Figure 4). Similar demethylation induced upregulation of SFRP2 and WIF1 expression was found in H1993 $(P=0.027)$ and H2073 $(P=0.017)$. These data suggested a potential impact of methylation on gene expression.
A

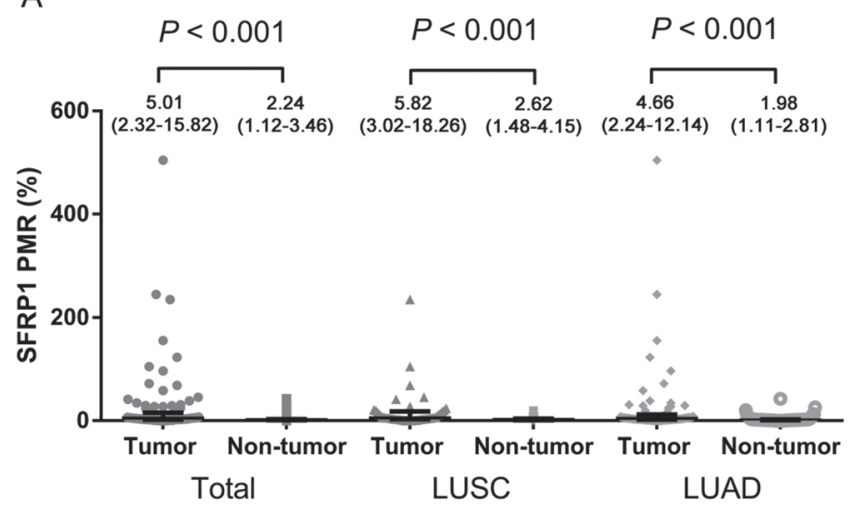

C

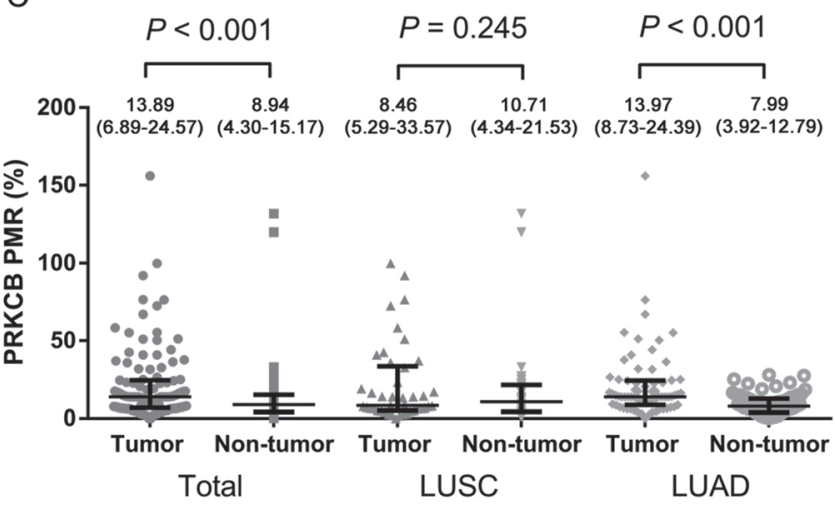

B

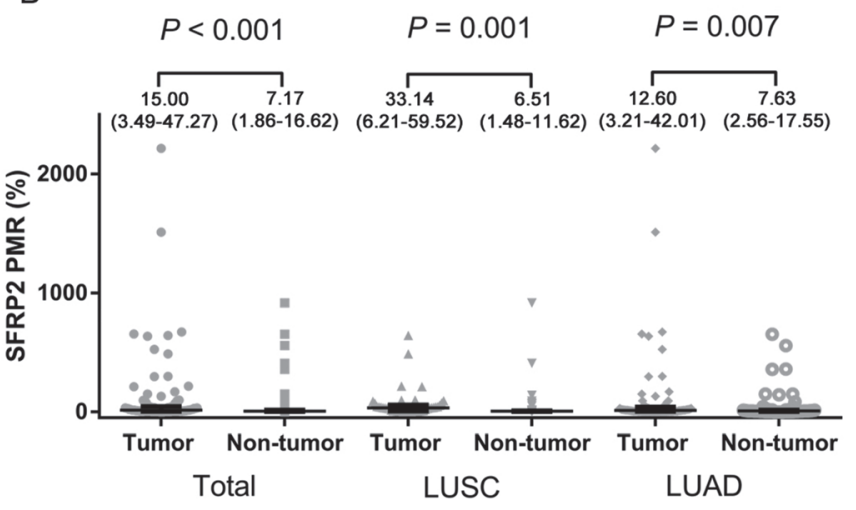

D

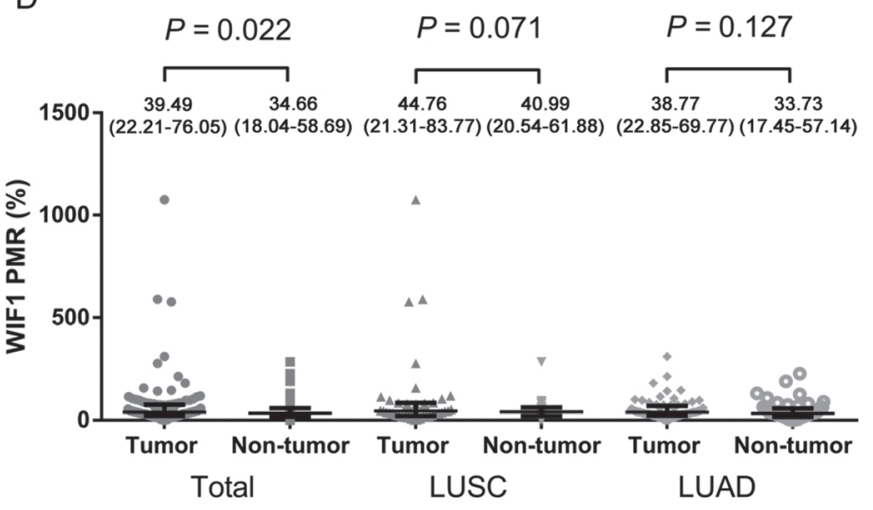

Figure 1: Comparisons of methylation levels of (A) SFRP1, (B) SFRP2, (C) PRKCB and (D) WIF1 genes between tumor tissues and paired adjacent non-tumor tissue. The error bars of PMR data were described as median (interquartile range). PMR: the percentage of methylated reference; LUAD: lung adenocarcinoma; LUSC: lung squamous carcinoma. 
Table 1: Association between the methylation status of SFRP1, SFRP2, PRKCB or WIF1 in 111 NSCLC patients and clinical pathological features

\begin{tabular}{|c|c|c|c|c|c|c|c|c|c|}
\hline \multirow{2}{*}{ Variables } & \multirow{2}{*}{$n$} & \multicolumn{2}{|l|}{ SFRP1 } & \multicolumn{2}{|l|}{ SFRP2 } & \multicolumn{2}{|l|}{$P R K C B$} & \multicolumn{2}{|l|}{ WIF1 } \\
\hline & & PMR (\%) & $P$ value & PMR (\%) & $P$ value & $\operatorname{PMR}(\%)$ & $P$ value & PMR (\%) & $P$ value \\
\hline Gender & & & 0.043 & & 0.007 & & 0.516 & & 0.785 \\
\hline Male & 73 & $5.81(2.96-19.73)$ & & $28.67(5.21-73.33)$ & & $13.89(6.61-36.20)$ & & $42.82(21.38-75.03)$ & \\
\hline Female & 38 & $3.06(2.14-8.61)$ & & $8.38(1.83-24.90)$ & & $13.89(7.42-19.49)$ & & $38.41(23.16-80.37)$ & \\
\hline Age (years) & & & 0.456 & & 0.769 & & 0.755 & & 0.306 \\
\hline$\leq 65$ & 62 & $4.70(2.39-11.15)$ & & $13.65(3.87-60.61)$ & & $13.89(6.57-24.68)$ & & $43.17(29.12-78.97)$ & \\
\hline$>65$ & 49 & $5.82(2.19-19.89)$ & & $20.28(3.29-43.49)$ & & $13.89(7.06-27.45)$ & & $33.66(19.58-70.71)$ & \\
\hline Smoking history & & & 0.234 & & 0.165 & & 0.979 & & 0.758 \\
\hline Nonsmoker & 50 & $3.88(2.14-12.59)$ & & $10.71(2.43-37.53)$ & & $13.89(7.14-25.42)$ & & $39.22(23.16-78.97)$ & \\
\hline Smoker & 61 & $5.81(2.68-18.74)$ & & $21.66(4.98-52.49)$ & & $13.89(6.61-24.39)$ & & $42.02(20.60-75.03)$ & \\
\hline Histological type & & & 0.355 & & 0.104 & & 0.178 & & 0.343 \\
\hline LUSC & 42 & $5.82(3.02-18.26)$ & & $33.14(6.21-59.52)$ & & $8.46(5.29-33.57)$ & & $44.76(21.31-83.77)$ & \\
\hline LUAD & 69 & $4.66(2.24-12.14)$ & & $12.60(3.21-42.01)$ & & $13.97(8.73-24.39)$ & & $38.77(22.82-69.77)$ & \\
\hline Clinical stage & & & 0.534 & & 0.968 & & 0.091 & & 0.844 \\
\hline $\mathrm{I}+\mathrm{II}$ & 88 & $4.99(2.34-11.98)$ & & $15.00(3.61-48.73)$ & & $13.89(6.56-22.66)$ & & $40.55(22.21-73.68)$ & \\
\hline III + IV & 23 & $5.22(2.27-24.11)$ & & $15.21(3.44-47.27)$ & & $14.93(8.02-42.54)$ & & $38.95(23.48-83.38)$ & \\
\hline Tumor location & & & 0.302 & & 0.797 & & 0.226 & & 0.744 \\
\hline Left lung & 46 & $5.66(2.93-18.48)$ & & $15.00(3.98-40.57)$ & & $14.34(7.22-33.57)$ & & $42.31(16.10-83.77)$ & \\
\hline Right lung & 65 & $4.66(2.24-12.85)$ & & $18.81(3.08-84.05)$ & & $12.90(6.61-23.73)$ & & $38.95(27.27-69.77)$ & \\
\hline Differentiation* & & & 0.762 & & 0.468 & & 0.326 & & 0.672 \\
\hline Poorly & 30 & $5.98(2.10-19.73)$ & & $20.97(4.51-49.36)$ & & $13.89(5.34-19.68)$ & & $38.47(27.05-76.13)$ & \\
\hline Moderately+well & 47 & $5.37(2.65-13.65)$ & & $8.96(3.49-39.86)$ & & $13.89(6.63-40.90)$ & & $38.95(16.21-85.18)$ & \\
\hline
\end{tabular}

Bold value indicates statistical significance. PMR data are represented as median (quartile). $P$ value is performed by MannWhitney test. * Partial information has not been recorded. LUSC: lung squamous carcinoma; LUAD: lung adenocarcinoma; PMR: the percentage of methylated reference

\section{Effects of candidate gene promoter regions on dual-luciferase activity}

Subsequent dual-luciferase reporter assays showed a significantly higher activity of $P R K C B$ promoter specific region ( $-580 \mathrm{bp}$ to $-180 \mathrm{bp})$ when compared with pGL3Basic vector (fold change $=2.47, P=0.002$, Figure 5), suggesting that $P R K C B$ promoter fragment was able to upregulate gene expression. However, no significant promoter activity could be found for the recombinant plasmids of SFRP1 (+464 bp to $+863 \mathrm{bp}), S F R P 2(+261$ bp to $+660 \mathrm{bp}$ ) and $\operatorname{WIFl}(-511 \mathrm{bp}$ to $111 \mathrm{bp})$.

\section{DISCUSSION}

Previously, most methylation studies has focused on single gene [21]. Here, we hypothesized that a panel of several genes might improve the diagnostic power for NSCLC. Our findings suggested that the DNA methylation levels of four Wnt pathway genes (SFRP1, $S F P R 2, P R K C B$ and $W I F 1$ ) could jointly predict the risk of NSCLC in both our cohort and TCGA cohort.

Dysregulation of Wnt signaling pathway is often implicated in cancer initiation [22]. Aberrant epigenetic regulation of Wnt pathway genes has been identified to be a common signature in adenocarcinoma [23]. Wnt antagonist or inhibitors are known as tumor suppressors, implying that hypermethylation-induced silencing of these tumor suppressor genes may participate in the pathogenesis or progression of human malignancies [24-26]. Therefore, we tested whether four candidate genes from canonical and non-canonical Wnt signaling pathway could accurately detect the risk of NSCLC. REporting recommendations for tumour MARKer prognostic studies (REMARK) guidelines have recently been applied in many journals to prevent relatively usefulness biomarkers and prognostic algorithms from being introduced [27]. In the current study, the Wntgene epigenetic panel should be treated as diagnostic 
Table 2: Association of candidate gene methylation levels and clinicopathologic variables with overall survival in NSCLC cohort

\begin{tabular}{|c|c|c|c|c|}
\hline Variables & Univariate HR (95\%CI) & Univariate $P$ value & Multivariate HR (95\%CI) & Multivariate $P$ value \\
\hline Age at surgery (years) & $0.994(0.937-1.054)$ & 0.838 & - & NA* \\
\hline Gender (Male/Female) & $1.304(0.345-4.932)$ & 0.696 & - & NA* \\
\hline Diagnosis (LUSC/LUAD) & $1.036(0.301-3.558)$ & 0.956 & - & NA* \\
\hline Disease stage (III+IV/ I+II) & $44.761(5.721-350.202)$ & $<0.001$ & $2.101(0.083-53.323)$ & 0.653 \\
\hline Smoking behavior (Yes/No) & $2.154(0.570-8.140)$ & 0.258 & - & NA* \\
\hline Tumor location (Left lung/Right lung) & $0.846(0.245-2.914)$ & 0.79 & - & NA* \\
\hline RECIST (PD/PR+SD) & $108.952(13.796-860.410)$ & $<0.001$ & $57.750(2.296-1452.838)$ & 0.014 \\
\hline SFRP1 methylation & $1.005(1.000-1.011)$ & 0.055 & $1.001(0.996-1.007)$ & 0.568 \\
\hline SFRP2 methylation & $1.000(0.998-1.002)$ & 0.788 & - & NA* \\
\hline$P R K C B$ methylation & $1.006(0.987-1.026)$ & 0.536 & - & NA* \\
\hline WIF1 methylation & $0.998(0.989-1.006)$ & 0.570 & - & NA* \\
\hline
\end{tabular}

Bold value indicates statistical significance. ${ }^{*}$ Not assessed due to an insignificant result in the univariate analysis $(P>0.1)$. Dichotomous data set the latter category as reference. PD: progressive disease; SD: stable disease; PR: partial response; HR: hazard ratio; CI: confidence interval; RECIST: Response Evaluation Criteria in Solid Tumors.

biomarkers rather than prognostic biomarkers [27].

The translational value of the epigenetic panel we have found may allow the early detection of lung cancer and represent an increased probability of cure for patients. At present, the diagnosis of NSCLC is mainly based on clinical symptoms, imaging detection and histopathological examination [28]. However, most of the patients' clinical symptoms appear relatively late, which challenges the outcome of NSCLC patients. Aberrant DNA methylation has been suggested as the early event during lung carcinogenesis [29]. Therefore, it shows a higher efficiency in the early detection. Epigenetic biomarkers may be a better tool for early diagnosis due to their preponderance of non-invasion, high sensitivity and high specificity [30]. Downregulation of Wnt inhibitors (e.g., by hypermethylation) is common in NSCLC tumor cell lines and resected samples [31]. Since epigenetic changes are dynamic and reversible, several inhibitors of enzymes controlling epigenetic modifications are promising targets for the development of more effective therapeutic strategies against cancer [32]. The two main DNA methyltransferase inhibitors that have been largely tested in the clinic are 5-azacitidine and decitabine [33].

There are several distinct types of cancer biomarkers based on different areas: proteomics, metabolomics, genetics and epigenetics [34]. Currently, conventional plasma proteins in clinical detection of lung cancer usually lack enough sensitivity in terms of their usages as biomarkers. For example, cytokeratin 19 fragment (CYFRA21-1) had a relatively low AUC of 0.624 (sensitivity: 0.576; specificity: 0.797 ) to discriminate NSCLC patients and control subjects [35], which suggested a lower diagnostic ability compared with our study. Moreover, previous study had confirmed that plasma CYFRA21-1 appeared more sensitive for NSCLC diagnosis than other tumor biomarkers such as carcinoembryonic antigen (CEA) and neuron-specific enolase (NSE) and progastrin-releasing peptide (ProGRP) [36]. DNA methylation emerged as a promising biomarker for early detection, which was independent of the genomic composition of the primary tumor [37]. However, intratumoral heterogeneity has profound clinical implications, which challenges the current methods of tumor diagnosis and targeted therapy [38]. Previous studies have reported the intratumor DNA methylation heterogeneity in human cancers [39-41]. Liquid biopsy was shown as an ideal means of sampling intratumor genetic and epigenetic heterogeneity for diagnostics [42]. Since DNA methylation as a biomarker was more effective in serum than that in tissues [43], future study is needed to check whether the panel of Wnt-gene epigenetic biomarkers has a higher diagnostic value in liquid biopsy. In order 
to assess the diagnostic capacity of the expression of four candidate genes, we have used the gene expression profiles (IlluminaHiSeq_RNA-SeqV2) of 817 NSCLC tumor samples and 29 non-tumor samples from TCGA database. As shown in Supplementary Figure 1, the results revealed that the AUC values of low expression of SFRP1, SFRP2, $W I F 1$ and $P R K C B$ were $0.705,0.319,0.959$ and 0.857 , respectively. SFRP2 expression did not draw a consistent conclusion like other genes, which implying a low efficiency of early detection. Although mRNA expression could be one of the distinct types of cancer biomarkers, it is advisable to establish a methylation-based diagnostic system for cancers since DNA methylation frequently regulates gene expression and occurs in the early stage of tumorigenesis [44].

Previous studies has reported the diagnostic values of SFRPI methylation in cutaneous squamous cell carcinoma [45] and esophageal squamous cell carcinoma recurrence [46]. SFRP2 hypermethylation has also been shown in several cancers including acute myeloblastic leukemia [47], mesothelioma [48], bladder cancer [49], liver cancer [50], as well as lung cancer [51]. SFRP2 hypermethylation was previously detected in women and nonsmoking NSCLC patients [52], indicating a gender-specific effect of DNA methylation on gene expression. Interestingly, our results revealed a more frequent SFRP1 and SFRP2 methylation in male NSCLC patients. This divergence may be due to the different patient populations and multiple environmental factors exposure. Since NSCLC is well-known to be composed of heterogeneous groups, sexual hormones have been considered to participate in some signaling pathway in NSCLC [53]. In human ovarian cancer, the ovarian hormones-induced Wnt pathway activation could increase the growth of ovarian cancer precursor lesions [54]. Meanwhile, cell proliferation could be accelerated by androgen and inhibited by estrogen [55]. Estrogen can influence neoplastic diseases by changing the levels of gene expression and DNA methylation $[56,57]$. Therefore, we speculated that the interaction of sexual hormones and Wnt signal pathway might be involved in the elevated DNA methylation in NSCLC patients.

WIF1 is a negative regulator of the Wnt pathway that may have important implications for tumorigenesis [58]. Clinical studies of WIF1 methylation or downregulation were particularly common in lung cancer $[59,60]$; however,
A
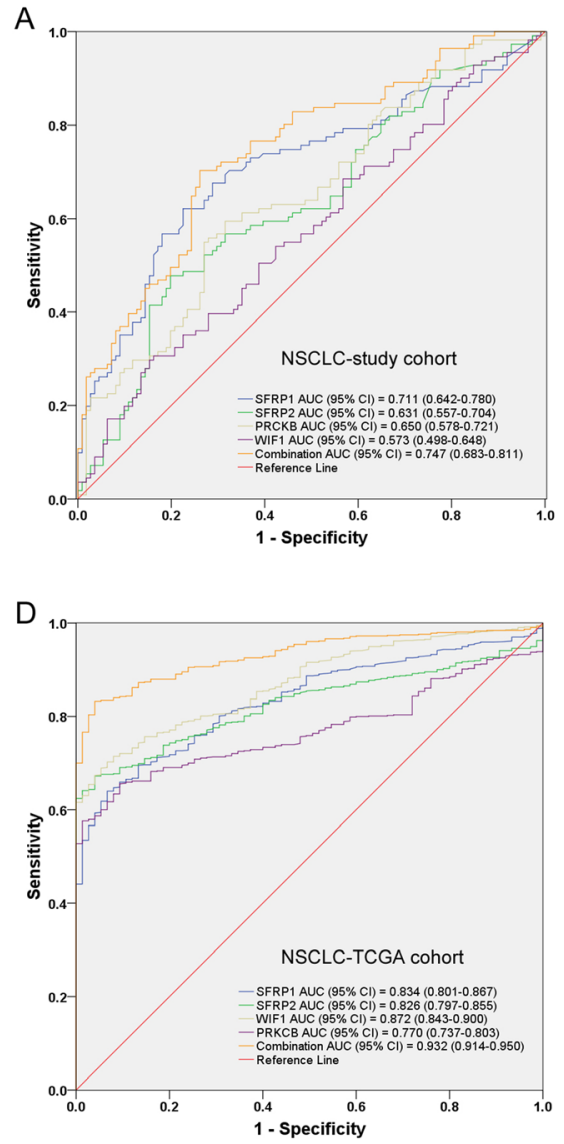

B

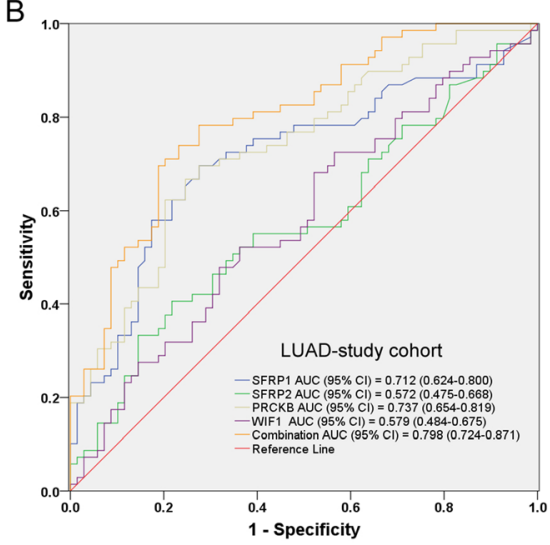

$\mathrm{E}$

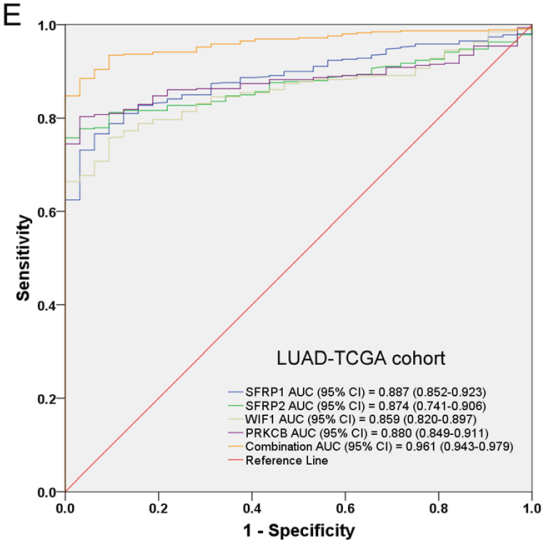

C

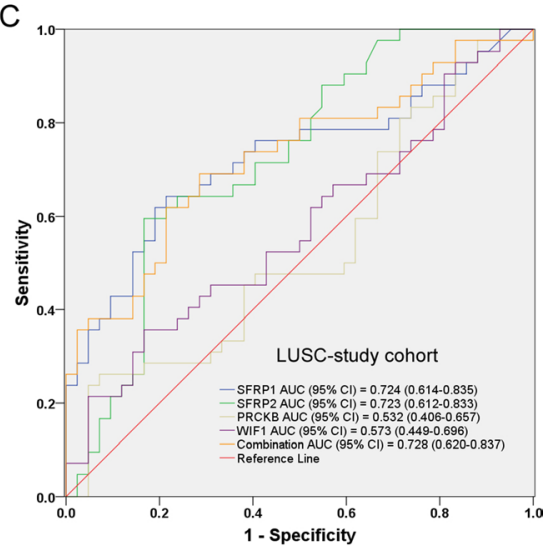

$\mathrm{F}$

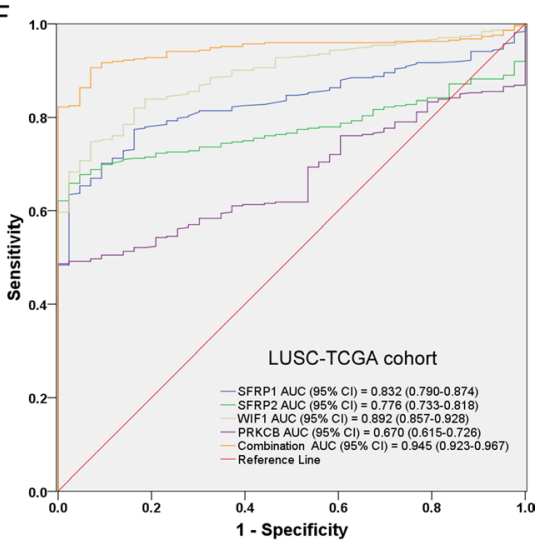

Figure 2: Receiver operating characteristic (ROC) curves for the methylation panel in (A) NSCLC, (B) LUAD and (C) LUSC of our study cohort and (D) NSCLC, (E) LUAD and (F) LUSC of TCGA cohort. AUC: area under the ROC curve; CI: confidence interval; NSCLC: non-small cell lung cancer; LUAD: lung adenocarcinoma; LUSC: lung squamous carcinoma; TCGA: The Cancer Genome Atlas. 
it had a weak diagnostic role in the current study. Methylation changes in carcinogenesis are often heterogeneous, and no single gene has been found to be methylated in every NSCLC specimen [59]. Therefore, further larger number of patients is needed to be investigated.

PRKCB was reported to enhance the expression of cyclin D1 in human breast cancer cells, leading to cell proliferation and cell cycle progression [61]. Its overexpression has been detected in chronic lymphocytic leukemia [62]. These findings suggested that $P R K C B$ was an important target for anticancer therapy. However, in the current study, higher methylation level of $P R K C B$ promoter was observed in tumor tissues than adjacent normal tissues. Our findings were consistent with the pan-cancer study of Li et al. [23]. They identified PRKCB promoter hypermethylation in LUAD, colon cancer and rectal cancer, showing $P R K C B$ as an epigeneticallysilenced gene in Wnt pathway. Besides, we observed a higher promoter activity of $P R K C B$, suggesting an important regulation of the transcriptional function. It is noteworthy to explore the exact mechanism of PRKCB promoter methylation on gene expression in NSCLC.

With analyzing TCGA data, we have found significant correlations for SFRP1_cg15839448, SFRP2 cg05774801,WIF1_cg21383810 methylation and their host gene expression, although the correlation coefficients were weak. Notably, results from GEO dataset gave a support that gene expression could be restored in some lung cancer cells after demethylation, to some extent, suggesting a potential effect of DNA methylation on gene silencing. Further dual luciferase assays showed that only $P R K C B$ promoter specific region had a significantly higher activity when compared with pGL3-Basic vector. All the above observations suggested the epigenetic regulation of four candidate genes were complex. There are two familiar mechanisms of DNA methylation on transcriptional repression. First, DNA methylation directly interferes with the combination of transcription factors and cis-element. Second, methyl-CpG-binding protein alters the chromatin structure by recruiting the co-repressor complex [63]. The purpose of the dual luciferase assays we have performed was to show that the promoter regions chosen might be functional. However, it is an intricate network of epigenetic regulation on gene expression. There may be other alternative mechanisms accounting for gene inactivation such as histone modifications (methylation, acetylation, and ubiquitination), chromatin remodeling, and non-coding ribonucleic acids (RNAs). Global profile changes of histone modifications are critical in the initiation and progression of human cancers [64, 65]. Cancer cells suffer a global reduction of activation markers H3K4me3 [66] and H4K16ac [67] and a gain
A
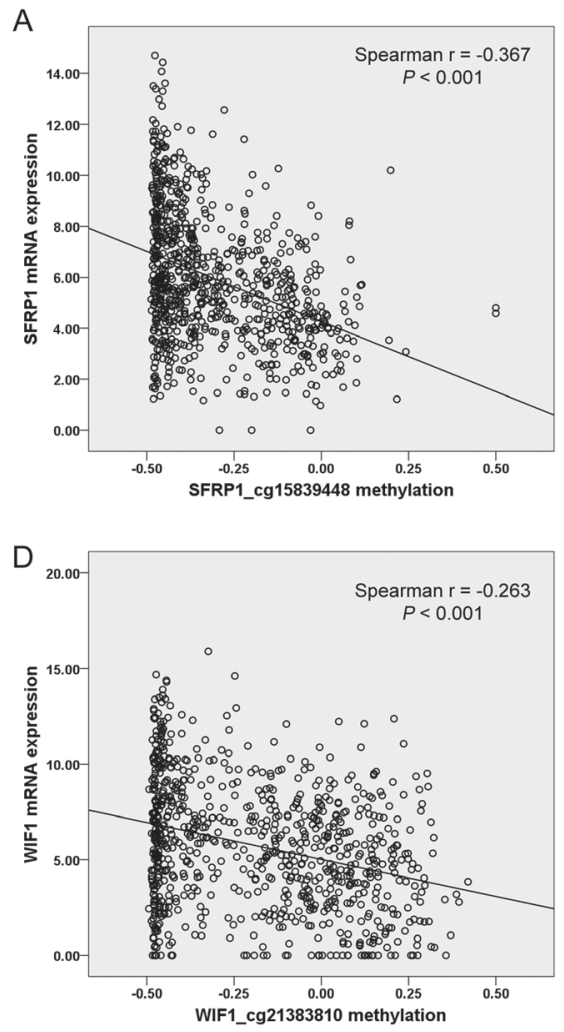

B

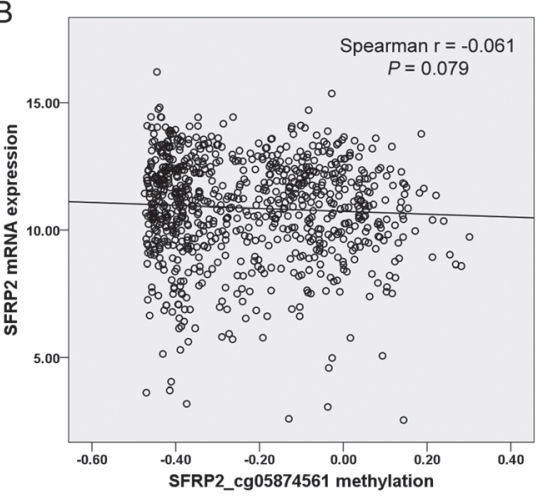

E

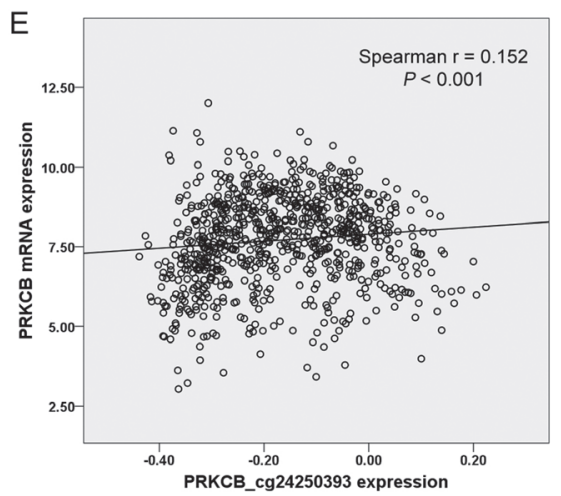

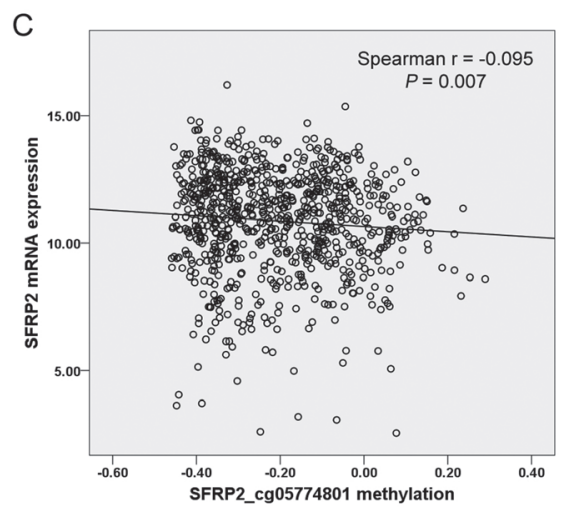

F

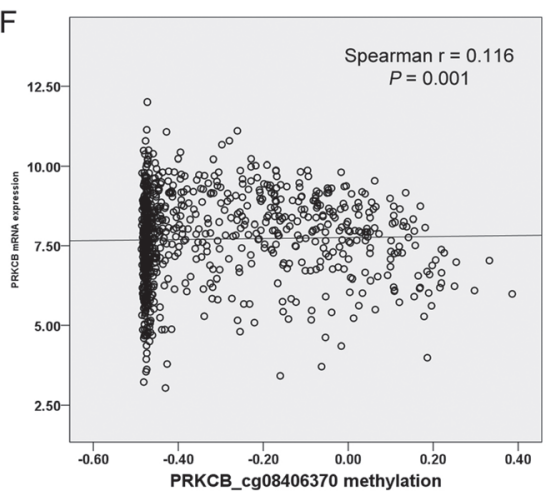

Figure 3: Correlation between 6 Illumina Human Methylation 450K CpG probes [(A)SFRP1_cg15839448, (B)SFRP2_ cg05874561, (C) SFRP2_cg05774801, (D) WIF1_cg21383810, (E) PRKCB_cg24250393 and (F) PRKCB_cg08406370] and corresponding gene expression in 818 NSCLC from TCGA data portal. NSCLC: non-small cell lung cancer; TCGA: The Cancer Genome Atlas. 
in the repressive markers $\mathrm{H} 3 \mathrm{~K} 27 \mathrm{me} 3$ [68], H3K9me3 [69] and H4K20me3 [67], which is closely related with transcriptional regulation. In esophageal squamous cell carcinoma, DNA methylation and histone acetylation has been found to synergize silencing SFRP1 gene expression [70]. Likewise, an aberrant gain of the repressive mark H3K27me3 could decrease the expression of SFRP1 gene in addition to DNA hypermethylation in prostate cancer cell line [71]. As for renal cell carcinoma, low levels of $\mathrm{AcH} 3, \mathrm{AcH} 4$ and $\mathrm{H} 3 \mathrm{~K} 4$ and a high level of $\mathrm{H} 3 \mathrm{~K} 9$, known as repressive histone modifications, were found in the SFRP2 negative cell lines [72]. Therefore, further investigations are required to elucidate the epigenetic control of Wnt signaling pathway in NSCLC.

There were some limitations of our study. First, FFPE samples are commonly used to find methylation and expression, although frequently genetic material in those samples is highly degraded [73]. FFPE samples were likely to yield false positives during formalin fixation process [74]. Future work is needed to validate the diagnostic values of the four candidate genes in fresh frozen biopsies or peripheral blood. Second, next generation sequencing (NGS) technique is superior to yield high-resolution DNA methylation information, such as the pattern information obtainable with bisulfate genomic sequencing or the accurate methylation percentage determination at single $\mathrm{CpG}$ site [75]. Although we have obtained a consistent result of the diagnostic value both in NGS-based TCGA data and our study, further validation in other NGS techniques is needed. The qMSP technique is high-throughput and sensitive, and it was often used in the clinical detection [76]. In the present study, due to the limitation of designing multiple suitable primer sets to assess the promoter region, we only evaluated a single $\mathrm{CpG}$ site to represent the methylation level of gene promoter region. Further investigations on other $\mathrm{CpG}$ sites among larger number of samples are needed to be carried out to clarify the epigenetic regulatory mechanism and its application to diagnostic biomarkers. Third, the sample size of our study was moderate, larger case-control studies from LUAD and LUSC patients need to be performed. Fourth, since the paired specimens have been obtained from the same patients, the data would not bear thorough analysis, i.e., stepwise multivariate analysis.

In summary, our study identified that a methylation panel of Wnt signal pathway genes (SFRP1, SFRP2, WIF1 and $P R K C B$ ) might be used as diagnostic biomarkers of NSCLC risk.

\section{MATERIALS AND METHODS}

\section{Sample collection}

Following the approval by the local Institutional Ethics Committee, a group of 111 primary NSCLC patients were recruited consecutively from Huzhou First People's Hospital, China from August 2010 to October 2013. None
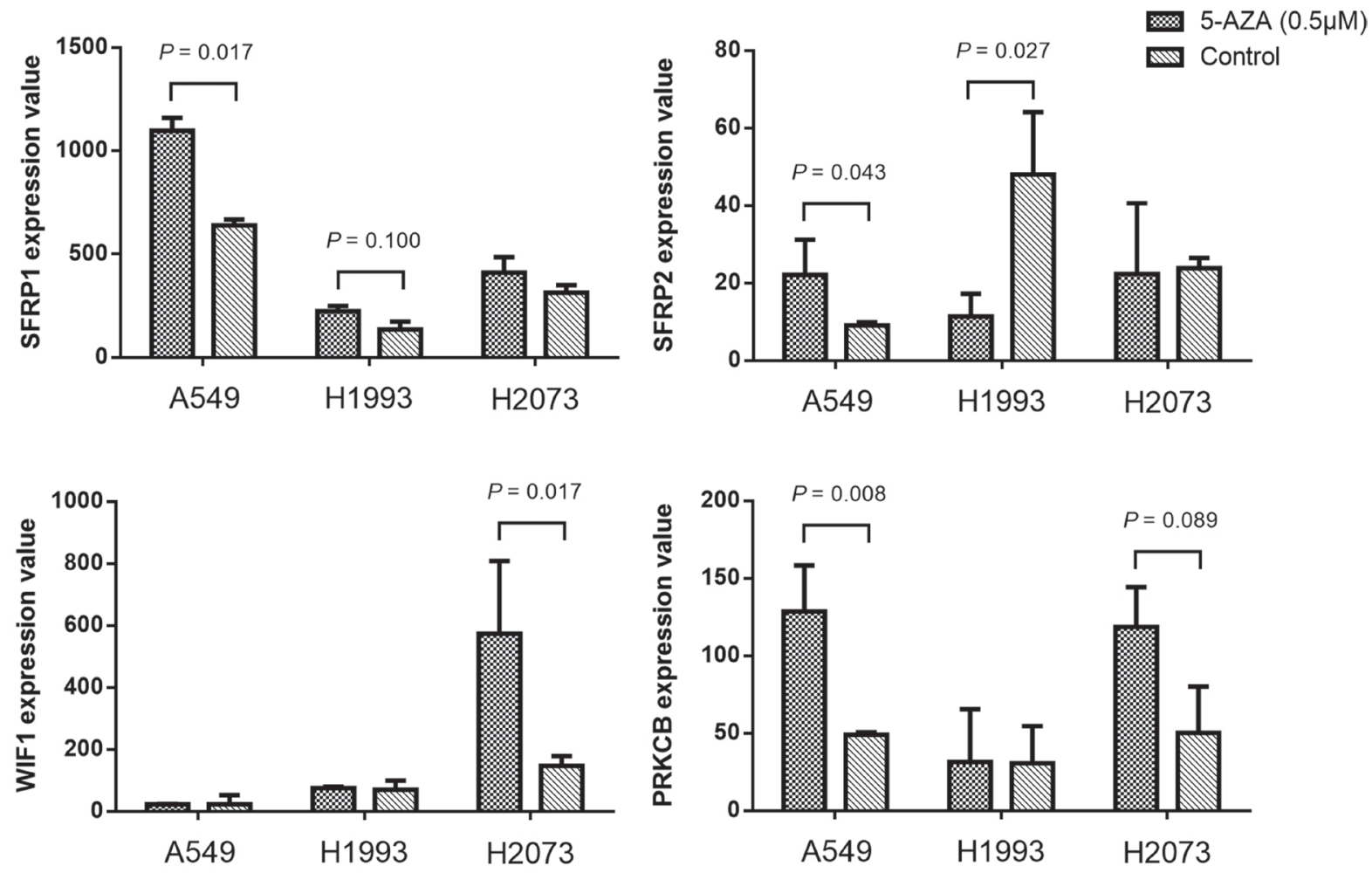

Figure 4: The expression value changes of SFRP1, SFRP2, WIF1 and PRKCB genes before and after 5'-Azadeoxycytidine (0.5 $\mu \mathrm{M}$ for 6 days) treatment in three NSCLC cell lines (A549, H1993 and H2073). $P$ value was evaluated by moderated t test. $P>0.10$ was not shown in the figure. 
of the patients received radiotherapy or chemotherapy before operation. These patients were diagnosed with LUAD or LUSC based on histopathological evaluation. There were 42 LUSC patients and 69 LUAD patients treated with cisplatinum-gemcitabine and cisplatinumpaclitaxel, respectively. Therapeutic effect was evaluated according to the RECIST 1.1 criteria [77]. Clinical features studied included age, gender, smoking history, clinical stage, tumor location and differentiation. The mean age of NSCLC patients (73 males and 38 females) was $63.59 \pm 10.19$ years. Staging was based on the TNM (tumor, node, metastasis) classification system of the International Union Against Cancer 2009 (UICC). Disease status after surgery for this cohort was updated every two months by telephone follow-up. OS refers to the data from the date of primary surgery to the date of death or the date of last follow-up. The study end point should be the death caused by NSCLC. The study set included 111-paired formalin-fixed, paraffin-embedded (FFPE) lung tumor tissues ( $4 \mu \mathrm{m}$ in thickness) and non-tumor tissues (4 $\mu \mathrm{m}$ in thickness) from Department of Pathology archives. All patients gave informed consent for collection and analysis of their tissue specimens for research purposes.

\section{Genomic DNA extraction and bisulfite modification}

The genomic DNA was isolated using the QIAamp DNA FFPE Tissue Kit following the manufacturer's instructions (Qiagen, Hilden, Germany). DNA was quantitated by the NanoDrop 2000 (Thermo Scientific,
Wilmington, USA). Sodium bisulfite modification was performed using EZ DNA Methylation Gold ${ }^{\mathrm{TM}}$ Kit (Zymo Research, Orange, CA). According to conversion principle, target sequence is modified converting unmethylated, but not methylated, cytosines to uracils, and uracils are subsequently converted into thymine following PCR reaction.

\section{Methylation assay by qMSP method}

For qMSP, primers specific for the $\mathrm{CpG}$ island sequences of the target genes (SFRP1, SFRP2, WIF1 and $P R K C B$ ) were designed to amplify bisulfite-modified DNA. $A C T B$ was used as an independent reference gene. The primer sequences were shown in Table 3. All experiments were performed on LightCycler 480 system (Roche Diagnostics Ltd, Lewes, UK) utilizing a 384-well plate platform. The amplification reaction was carried out in a final volume of $10 \mu \mathrm{L}$ containing $5 \mu \mathrm{L}$ LightCycler 480 SYBR Green I Master (Roche Diagnostics Ltd, Lewes, UK), $0.5 \mu \mathrm{L}$ DNA template, $0.25 \mu \mathrm{L}$ of each primer $(10 \mu \mathrm{M})$ and $4.0 \mu \mathrm{L} \mathrm{H}_{2} \mathrm{O}$. The PCR program was as follows: holding at $95^{\circ} \mathrm{C} 10 \mathrm{~min}$ for enzyme activation, 45 cycles of denaturation at $95^{\circ} \mathrm{C}$ for $20 \mathrm{~s}$, annealing at $56^{\circ} \mathrm{C}$ or $58^{\circ} \mathrm{C}$ for $20 \mathrm{~s}$, and extension at $72^{\circ} \mathrm{C}$ for $30 \mathrm{~s}$. After amplification, melting curve analysis was performed for PCR product identification that consisted of one cycle of $95^{\circ} \mathrm{C}$ for $15 \mathrm{~s}, 60^{\circ} \mathrm{C}$ for $60 \mathrm{~s}$, and $95^{\circ} \mathrm{C}$ for continuous acquisition mode. SssI methyltransferase (Thermo Scientific, Wilmington, USA) and bisulfitetreated leukocyte DNA from healthy person served as a positive methylation control. Water without DNA served

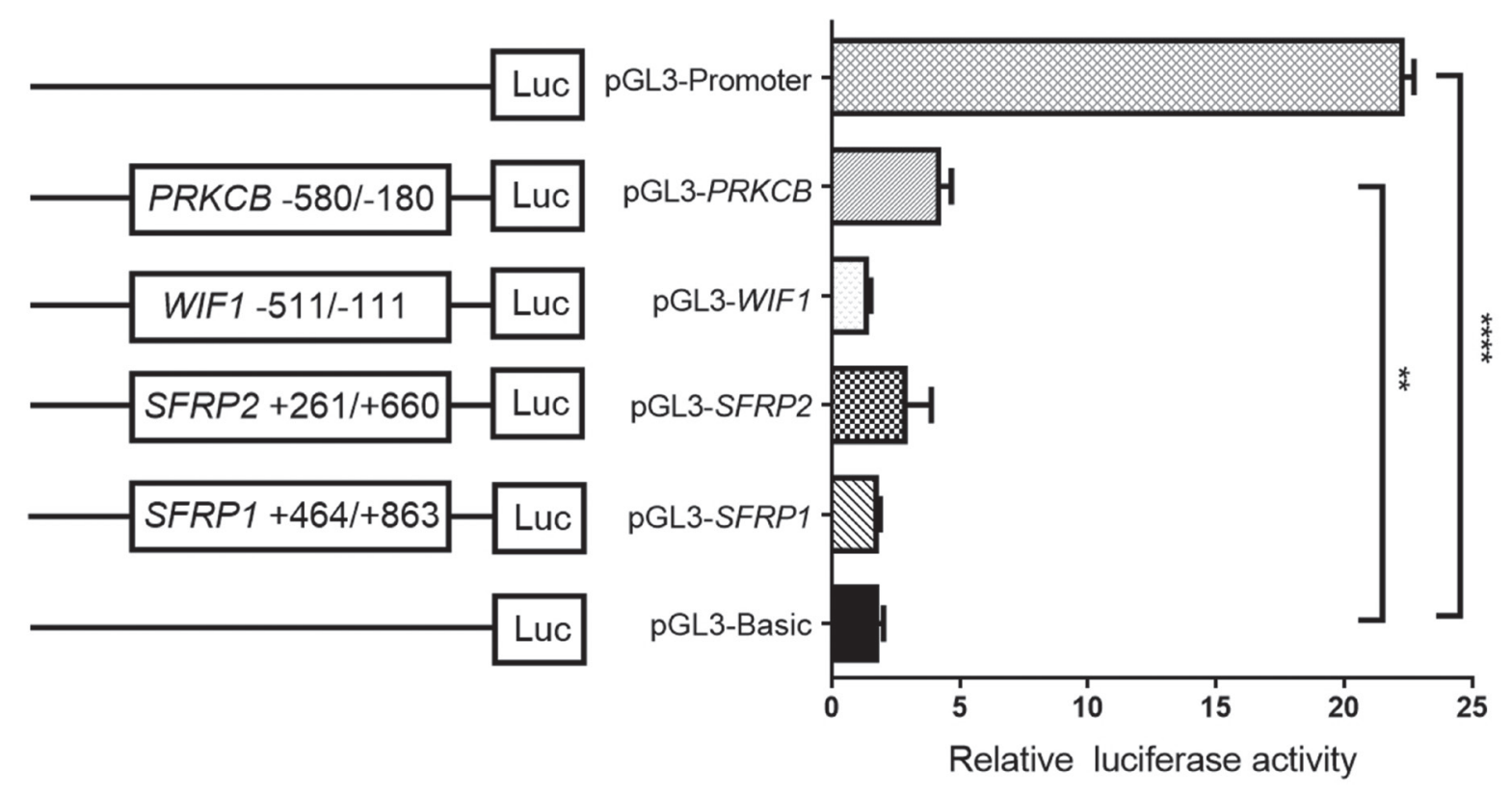

Figure 5: Luciferase activity determined by a dual-luciferase assay system. The reporter gene plasmids containing different gene promoter regions were constructed, including pGL3-SFRP1: +464 to +863, pGL3-SFRP2: +261 to +660, pGL3-WIF1: -511 to -111 , and pGL3-PRKCB: -580 to -180 . HEK-293T cells were transfected with each reporter gene plasmid, together with renilla luciferase reporter plasmid. Empty pGL3-Basic and pGL3-Promoter vectors were used as the negative and positive control, respectively. $* * P<0.01$; $* * * * P<0.0001$. 
Table 3: Primer sequences used to amplify bisulphite converted DNA in qMSP analysis

\begin{tabular}{|c|c|c|c|c|}
\hline Gene & Forward primer $\left(5^{\prime}-3^{\prime}\right)$ & Reverse primer $\left(5^{\prime}-3^{\prime}\right)$ & $\begin{array}{l}\text { Product } \\
\text { (bp) }\end{array}$ & $\operatorname{Tm}\left({ }^{\circ} \mathbf{C}\right)$ \\
\hline SFRP1 & GAAGAGCGAGTAGAGGAA & ACACGAAACCATAACGAAA & 103 & 58 \\
\hline SFRP2 & AAGAGCGAGTATAGGAAT & ССТАССААССТАСААСТА & 167 & 56 \\
\hline WIF1 & TCGGAGAAGGGTATTTAGAGA & CCATCATCAACACTCAATCAA & 123 & 58 \\
\hline$P R K C B$ & TGTAAGTGTGTGCGGTTAT & CCCATCCATCCCATTAATCA & 96 & 58 \\
\hline$A C T B(1)$ & GTGATGGAGGAGGTTTAGTAAGTT & ССАAТАAААССТАСТССТСССТТАA & 129 & 56 \\
\hline$A C T B(2)$ & TGGTGATGGAGGAGGTTTAGTAAGT & AАCСАAТАAАACСТАСТССТСССТТАА & 133 & 58 \\
\hline
\end{tabular}

The primers of $A C T B$ (1) were designed for 56 annealing temperature. The primers of $A C T B$ (2) were designed for 58 annealing temperature.

as a control for contamination was included in each assay. Each reaction was performed in duplicate. PCR products were subjected to the Qsep100 DNA fragment analyzer (Bioptic, Taiwan, China) and visualized in Gel-view format. Subsequently, some qMSP products' sequences were verified by Applied Biosystems ${ }^{\circledR} 3730$ DNA Analyzer (Applied Biosystems, Warrington, UK) (Supplementary Figures 2-5).

\section{Public database analysis for methylation- expression correlation}

DNA methylation profiles (Illumina Human Methylation 450K, HM450K) generated from 415 LUSC samples (372 tumor tissues and 43 non-tumor tissues) and 490 LUAD samples (458 tumor tissues and 32 non-tumor tissues), and gene expression profiles (IlluminaHiSeq RNA-SeqV2) generated from 371 LUSC tumor tissues and 447 LUAD tumor tissues were available from the Cancer Genomics Browser (https://genome-cancer.ucsc. edu/). The corresponding TCGA data of 6 HM450K CpG probes (SFRP1_cg15839448, SFRP2_cg05874561, SFRP2_cg05774801, WIF1_cg21383810, PRKCB cg24250393 and $P R K C B \_$cg08406370) were extracted to explore the regulatory mechanism of $\mathrm{CpG}$ island DNA methylation on gene expression. The expression value of SFRP1, SFRP 2, WIF1 and PRKCB genes before and after 5 '-AZA $(0.5 \mu \mathrm{M}$ for 6 days) treatment in 3 NSCLC cell lines (A549, H1993 and H2073) were obtained from GEO database. The accession number is GSE32496.

\section{Dual luciferase reporter assay}

The fragments of SFRP1 promoter $(+464$ bp to +863bp), SFRP2 promoter (+261 bp to $+660 \mathrm{bp})$, WIF1 promoter ( $-511 \mathrm{bp}$ to $-111 \mathrm{bp}$ ), and $P R K C B$ promoter $(-580 \mathrm{bp}$ to $-180 \mathrm{bp})$ were chemically synthesized. All amplified promoter DNA fragments were digested with XhoI and NheI. The details of cell culture, construction of recombinant plasmids, plasmids transfection and luciferase reporter assay procedures were as previously described [78].

\section{Statistical analysis}

PMR at a specific region was calculated by dividing the gene : ACTB ratio of a sample by the gene : ACTB ratio of fully methylated DNA and multiplying by 100 . The PMR cut-off point (i.e., the value with the maximum Youden index, defined as sensitivity plus specificity minus 1) was calculated using the ROC curve. Data were presented as median (interquartile range). The MannWhitney test was used to study the differences in the nonparameter variables. ROC curves were constructed and the AUCs were calculated to determine the diagnostic role of four genes methylation for NSCLC. Multivariate analysis was performed for OS after excluding the insignificant variables on univariate analysis $(P>0.01)$. Cox proportional hazard models were fitted with calculating hazard ratios (HR) and the corresponding 95\% confidence intervals $(95 \% \mathrm{CI})$. Nonparametric Spearman's criterion was used to calculate the coefficient of correlation between the levels of mRNA expression and promoter methylation from TCGA datasets. The results of luciferase reporter assay represented the means \pm standard deviation of triplicate determinations. Statistical analysis was performed using SPSS version 18.0, with all tests being two-tailed and $P<0.05$ was considered to be statistically significant.

\section{Abbreviations}

NSCLC: non-small cell lung cancer, qMSP: quantitative methylation-specific polymerase chain reaction. LUSC: lung squamous carcinoma, LUAD: lung adenocarcinoma, SFRP: secreted frizzled related protein, WIF1: Wnt inhibitory factor-1, PRKCB: protein kinase $\mathrm{C}$ beta, PMR: the percentage of methylated reference, ROC: receiver operating characteristic, AUC: area under the curve, TCGA: The Cancer Genome Atlas, OS: overall survival, FFPE: formalin-fixed, paraffin-embedded, RECIST: response evaluation criteria in solid tumors, TNM: tumor, node, metastasis, REMARK: REporting recommendations for tumour MARKer prognostic studies. 


\section{Authors' contributions}

$\mathrm{SL}, \mathrm{XC}, \mathrm{SD}$ and JH conceived of and designed the study. SL, XC, RC, JW and GZ performed the experiments. SL, XC, HW and JJ performed the analyses. RC and JW prepared all figures and tables. XC, SL and HW wrote the main manuscript. All the authors reviewed the manuscript.

\section{ACKNOWLEDGMENTS}

We would like to thank the TCGA and GEO databases for their open access. The research was supported by the grants from the National Natural Science Foundation of China (No. 81371469), Natural Science Foundation for the Youth (No. 81402220), Zhejiang Provincial Natural Science Foundation (No. LY14H160008), Suzhou Planning Project of Science and Technology (No. SYS201301), and K. C. Wong Magna Fund in Ningbo University.

\section{CONFLICTS OF INTEREST}

The authors declare no conflicts of interest.

\section{REFERENCES}

1. Chen W, Zheng R, Baade PD, Zhang S, Zeng H, Bray F, Jemal A, Yu XQ, He J. Cancer statistics in China, 2015. CA Cancer J Clin. 2016; 66:115-132.

2. Duan H, Luan J, Liu Q, Yagasaki K, Zhang G. Suppression of human lung cancer cell growth and migration by berbamine. Cytotechnology. 2010; 62:341-348.

3. Dubey S, Powell CA. Update in lung cancer 2008. Am J Respir Crit Care Med. 2009; 179:860-868.

4. Ansari J, Shackelford RE, El-Osta H. Epigenetics in non-small cell lung cancer: from basics to therapeutics. Transl Lung Cancer Res. 2016; 5:155-171.

5. De Jong WK, Verpooten GF, Kramer H, Louwagie J, Groen HJ. Promoter methylation primarily occurs in tumor cells of patients with non-small cell lung cancer. Anticancer Res. 2009; 29:363-369.

6. Belinsky SA. Gene-promoter hypermethylation as a biomarker in lung cancer. Nat Rev Cancer. 2004; 4:707-717.

7. Stewart DJ, Chang DW, Ye Y, Spitz M, Lu C, Shu X, Wampfler JA, Marks RS, Garces YI, Yang P, Wu X. Wnt signaling pathway pharmacogenetics in non-small cell lung cancer. Pharmacogenomics J. 2014; 14:509-522.

8. Kawano Y, Kypta R. Secreted antagonists of the Wnt signalling pathway. J Cell Sci. 2003; 116:2627-2634.

9. Galamb O, Kalmar A, Peterfia B, Csabai I, Bodor A, Ribli D, Krenacs T, Patai AV, Wichmann B, Bartak BK, Toth K, Valcz G, Spisak S, et al. Aberrant DNA methylation of WNT pathway genes in the development and progression of CIMPnegative colorectal cancer. Epigenetics. 2016; 11:588-602.

10. Kishino T, Niwa T, Yamashita S, Takahashi T, Nakazato H, Nakajima T, Igaki H, Tachimori Y, Suzuki Y, Ushijima T.
Integrated analysis of DNA methylation and mutations in esophageal squamous cell carcinoma. Mol Carcinog. 2016; 55:2077-2088.

11. Majchrzak-Celinska A, Slocinska M, Barciszewska AM, Nowak S, Baer-Dubowska W. Wnt pathway antagonists, SFRP1, SFRP2, SOX17, and PPP2R2B, are methylated in gliomas and SFRP1 methylation predicts shorter survival. J Appl Genet. 2016; 57:189-197.

12. Zheng L, Sun D, Fan W, Zhang Z, Li Q, Jiang T. Diagnostic value of SFRP1 as a favorable predictive and prognostic biomarker in patients with prostate cancer. PLoS one. 2015; 10:e0118276.

13. Amornpisutt R, Proungvitaya S, Jearanaikoon P, Limpaiboon T. DNA methylation level of OPCML and SFRP1: a potential diagnostic biomarker of cholangiocarcinoma. Tumour Biol. 2015; 36:4973-4978.

14. Zhang Y, Wang R, Song H, Huang G, Yi J, Zheng Y, Wang J, Chen L. Methylation of multiple genes as a candidate biomarker in non-small cell lung cancer. Cancer Lett. 2011; 303:21-28.

15. Zhu J, Wang Y, Duan J, Bai H, Wang Z, Wei L, Zhao J, Zhuo M, Wang S, Yang L, An T, Wu M, Wang J. DNA Methylation status of Wnt antagonist SFRP5 can predict the response to the EGFR-tyrosine kinase inhibitor therapy in nonsmall cell lung cancer. J Exp Clin Cancer Res. 2012; 31:80.

16. Licchesi JD, Westra WH, Hooker CM, Machida EO, Baylin SB, Herman JG. Epigenetic alteration of Wnt pathway antagonists in progressive glandular neoplasia of the lung. Carcinogenesis. 2008; 29:895-904.

17. Murray NR, Davidson LA, Chapkin RS, Clay Gustafson W, Schattenberg DG, Fields AP. Overexpression of protein kinase C betaII induces colonic hyperproliferation and increased sensitivity to colon carcinogenesis. J Cell Biol. 1999; 145:699-711.

18. Pradhan MP, Desai A, Palakal MJ. Systems biology approach to stage-wise characterization of epigenetic genes in lung adenocarcinoma. BMC Syst Biol. 2013; 7:141.

19. Lambert MP, Paliwal A, Vaissiere T, Chemin I, Zoulim F, Tommasino M, Hainaut P, Sylla B, Scoazec JY, Tost J, Herceg Z. Aberrant DNA methylation distinguishes hepatocellular carcinoma associated with HBV and HCV infection and alcohol intake. J Hepatol. 2011; 54:705-715.

20. Araujo OC, Rosa AS, Fernandes A, Niel C, VillelaNogueira CA, Pannain V, Araujo NM. RASSF1A and DOK1 Promoter Methylation Levels in Hepatocellular Carcinoma, Cirrhotic and Non-Cirrhotic Liver, and Correlation with Liver Cancer in Brazilian Patients. PLoS one. 2016; 11:e153796.

21. Van De Voorde L, Speeckaert R, Van Gestel D, Bracke M, De Neve W, Delanghe J, Speeckaert M. DNA methylation-based biomarkers in serum of patients with breast cancer. Mutat Res. 2012; 751:304-325.

22. Reya $\mathrm{T}, \mathrm{Clevers} \mathrm{H.} \mathrm{Wnt} \mathrm{signalling} \mathrm{in} \mathrm{stem} \mathrm{cells} \mathrm{and} \mathrm{cancer.}$ Nature. 2005; 434:843-850.

23. Li J, Huang KL, Zhang T, Li H, Zhao J, Wang H. Pan-cancer methylation and expression profiling of adenocarcinomas 
revealed epigenetic silencing in the WNT signaling pathway. Neoplasma. 2016; 63:208-214.

24. Yu J, Tao Q, Cheng YY, Lee KY, Ng SS, Cheung KF, Tian L, Rha SY, Neumann U, Rocken C, Ebert MP, Chan FK, Sung JJ. Promoter methylation of the Wnt/beta-catenin signaling antagonist Dkk-3 is associated with poor survival in gastric cancer. Cancer. 2009; 115:49-60.

25. Urakami S, Shiina H, Enokida H, Kawakami T, Kawamoto K, Hirata H, Tanaka Y, Kikuno N, Nakagawa M, Igawa M, Dahiya R. Combination analysis of hypermethylated Wnt-antagonist family genes as a novel epigenetic biomarker panel for bladder cancer detection. Clin Cancer Res. 2006; 12:2109-2116.

26. Urakami S, Shiina H, Enokida H, Hirata H, Kawamoto K, Kawakami T, Kikuno N, Tanaka Y, Majid S, Nakagawa M, Igawa M, Dahiya R. Wnt antagonist family genes as biomarkers for diagnosis, staging, and prognosis of renal cell carcinoma using tumor and serum DNA. Clin Cancer Res. 2006; 12:6989-6997.

27. McShane LM, Altman DG, Sauerbrei W, Taube SE, Gion M, Clark GM, Statistics Subcommittee of the NCIEWGoCD. REporting recommendations for tumour MARKer prognostic studies (REMARK). Br J Cancer. 2005; 93:387-391.

28. Anglim PP, Alonzo TA, Laird-Offringa IA. DNA methylationbased biomarkers for early detection of non-small cell lung cancer: an update. Mol Cancer. 2008; 7:81.

29. Di Paolo A, Del Re M, Petrini I, Altavilla G, Danesi R. Recent advances in epigenomics in NSCLC: real-time detection and therapeutic implications. Epigenomics. 2016; 8:1151-1167.

30. Mehta A, Dobersch S, Romero-Olmedo AJ, Barreto G. Epigenetics in lung cancer diagnosis and therapy. Cancer Metastasis Rev. 2015; 34:229-241.

31. Stewart DJ. Wnt signaling pathway in non-small cell lung cancer. J Natl Cancer Inst. 2014; 106:djt356.

32. Egger G, Liang G, Aparicio A, Jones PA. Epigenetics in human disease and prospects for epigenetic therapy. Nature. 2004; 429:457-463.

33. Forde PM, Brahmer JR, Kelly RJ. New strategies in lung cancer: epigenetic therapy for non-small cell lung cancer. Clin Cancer Res. 2014; 20:2244-2248.

34. Sung HJ, Cho JY. Biomarkers for the lung cancer diagnosis and their advances in proteomics. BMB Rep. 2008; 41:615-625.

35. Wang X, Zhi X, Zhang Y, An G, Feng G. Role of plasma MicroRNAs in the early diagnosis of non-small-cell lung cancers: a case-control study. J Thorac Dis. 2016; 8:1645-1652.

36. Schneider J, Philipp M, Velcovsky HG, Morr H, Katz N. Pro-gastrin-releasing peptide (ProGRP), neuron specific enolase (NSE), carcinoembryonic antigen (CEA) and cytokeratin 19-fragments (CYFRA 21-1) in patients with lung cancer in comparison to other lung diseases. Anticancer Res. 2003; 23:885-893.

37. Lissa D, Robles AI. Methylation analyses in liquid biopsy. Transl Lung Cancer Res. 2016; 5:492-504.
38. Rybinski B, Yun K. Addressing intra-tumoral heterogeneity and therapy resistance. Oncotarget. 2016; 7:72322-72342. doi: 10.18632/oncotarget.11875.

39. Hao JJ, Lin DC, Dinh HQ, Mayakonda A, Jiang YY, Chang C, Jiang Y, Lu CC, Shi ZZ, Xu X, Zhang Y, Cai Y, Wang JW, et al. Spatial intratumoral heterogeneity and temporal clonal evolution in esophageal squamous cell carcinoma. Nat Genet. 2016; 48:1500-1507.

40. Brocks D, Assenov Y, Minner S, Bogatyrova O, Simon R, Koop C, Oakes C, Zucknick M, Lipka DB, Weischenfeldt J, Feuerbach L, Cowper-Sal Lari R, Lupien M, et al. Intratumor DNA methylation heterogeneity reflects clonal evolution in aggressive prostate cancer. Cell Rep. 2014; 8:798-806.

41. Landau DA, Clement K, Ziller MJ, Boyle P, Fan J, Gu H, Stevenson K, Sougnez C, Wang L, Li S, Kotliar D, Zhang W, Ghandi $\mathrm{M}$, et al. Locally disordered methylation forms the basis of intratumor methylome variation in chronic lymphocytic leukemia. Cancer Cell. 2014; 26:813-825.

42. Pisanic TR 2nd, Athamanolap P, Poh W, Chen C, Hulbert A, Brock MV, Herman JG, Wang TH. DREAMing: a simple and ultrasensitive method for assessing intratumor epigenetic heterogeneity directly from liquid biopsies. Nucleic Acids Res. 2015; 43:e154.

43. Ling ZQ, Lv P, Lu XX, Yu JL, Han J, Ying LS, Zhu X, Zhu WY, Fang XH, Wang S, Wu YC. Circulating Methylated XAF1 DNA Indicates Poor Prognosis for Gastric Cancer. PLoS one. 2013; 8:e67195.

44. Tommasi S, Karm DL, Wu X, Yen Y, Pfeifer GP. Methylation of homeobox genes is a frequent and early epigenetic event in breast cancer. Breast Cancer Res. 2009; 11:R14.

45. Liang J, Kang X, Halifu Y, Zeng X, Jin T, Zhang M, Luo D, Ding Y, Zhou Y, Yakeya B, Abudu D, Pu X. Secreted frizzledrelated protein promotors are hypermethylated in cutaneous squamous carcinoma compared with normal epidermis. BMC cancer. 2015; 15:641.

46. Liu JB, Qiang FL, Dong J, Cai J, Zhou SH, Shi MX, Chen KP, $\mathrm{Hu}$ ZB. Plasma DNA methylation of Wnt antagonists predicts recurrence of esophageal squamous cell carcinoma. World J Gastroenterol. 2011; 17:4917-4921.

47. Ghasemi A, Rostami S, Chahardouli B, Alizad Ghandforosh N, Ghotaslou A, Nadali F. Study of SFRP1 and SFRP2 methylation status in patients with de novo Acute Myeloblastic Leukemia. Int J Hematol Oncol Stem Cell Res. 2015; 9:15-21.

48. Kohno H, Amatya VJ, Takeshima Y, Kushitani K, Hattori N, Kohno N, Inai K. Aberrant promoter methylation of WIF-1 and SFRP1, 2, 4 genes in mesothelioma. Oncol Rep. 2010; 24:423-431.

49. Marsit CJ, Karagas MR, Andrew A, Liu M, Danaee H, Schned AR, Nelson HH, Kelsey KT. Epigenetic inactivation of SFRP genes and TP53 alteration act jointly as markers of invasive bladder cancer. Cancer Res. 2005; 65:7081-7085.

50. Muller HM, Oberwalder M, Fiegl H, Morandell M, Goebel G, Zitt M, Muhlthaler M, Ofner D, Margreiter R, Widschwendter M. Methylation changes in faecal DNA: 
a marker for colorectal cancer screening? Lancet. 2004; 363:1283-1285.

51. Xie J, Zhang Y, Hu X, Lv R, Xiao D, Jiang L, Bao Q. Norcantharidin inhibits Wnt signal pathway via promoter demethylation of WIF-1 in human non-small cell lung cancer. Med Oncol. 2015; 32:145.

52. Suzuki M, Shigematsu H, Nakajima T, Kubo R, Motohashi S, Sekine Y, Shibuya K, Iizasa T, Hiroshima K, Nakatani Y, Gazdar AF, Fujisawa T. Synchronous alterations of Wnt and epidermal growth factor receptor signaling pathways through aberrant methylation and mutation in non small cell lung cancer. Clin Cancer Res. 2007; 13:6087-6092.

53. Berardi R, Morgese F, Santinelli A, Onofri A, Biscotti T, Brunelli A, Caramanti M, Savini A, De Lisa M, Ballatore Z, Pompili C, Salati M, Mazzanti P, et al. Hormonal receptors in lung adenocarcinoma: expression and difference in outcome by sex. Oncotarget. 2016; 7:82648-82657. doi: 10.18632/ oncotarget.12244.

54. Nagendra PB, Goad J, Nielsen S, Rassam L, Lombard JM, Nahar P, Tanwar PS. Ovarian hormones through Wnt signalling regulate the growth of human and mouse ovarian cancer initiating lesions. Oncotarget. 2016; 7:64836-64853. doi: 10.18632/oncotarget.11711.

55. Li Y, Li H, Spitsbergen JM, Gong Z. Males develop faster and more severe hepatocellular carcinoma than females in krasV12 transgenic zebrafish. Sci Rep. 2017; 7:41280.

56. Watanabe M, Honda C, The Osaka Twin Research Group, Iwatani Y, Yorifuji S, Iso H, Kamide K, Hatazawa J, Kihara S, Sakai N, Watanabe H, Makimoto K, Watanabe M, et al. Within-pair differences of DNA methylation levels between monozygotic twins are different between male and female pairs. BMC Med Genomics. 2016; 9:55.

57. Jiang D, Wang Y, Shen Y, Xu Y, Zhu H, Wang J, Wang H, Duan S. Estrogen and promoter methylation in the regulation of PLA2G7 transcription. Gene. 2016; 591:262-267.

58. Lee SM, Park JY, Kim DS. Wifl hypermethylation as unfavorable prognosis of non-small cell lung cancers with EGFR mutation. Mol Cells. 2013; 36:69-73.

59. Huang T, Chen X, Hong Q, Deng Z, Ma H, Xin Y, Fang Y, Ye H, Wang R, Zhang C, Ye M, Duan S. Meta-analyses of gene methylation and smoking behavior in non-small cell lung cancer patients. Sci Rep. 2015; 5:8897.

60. Korobko EV, Kalinichenko SV, Shepelev MV, Zborovskaia IB, Allakhverdiev AK, Zinov'eva MV, Vinogradova TV, Sverdlov ED, Korobko IV. [Suppression of WIFI transcript and protein in non-small cell lung carcinomas]. [Article in Russian]. Mol Gen Mikrobiol Virusol. 2007; 13-18.

61. Li H, Weinstein IB. Protein kinase $\mathrm{C}$ beta enhances growth and expression of cyclin D1 in human breast cancer cells. Cancer Res. 2006; 66:11399-11408.

62. Abrams ST, Lakum T, Lin K, Jones GM, Treweeke AT, Farahani M, Hughes M, Zuzel M, Slupsky JR. B-cell receptor signaling in chronic lymphocytic leukemia cells is regulated by overexpressed active protein kinase CbetaII. Blood. 2007; 109:1193-1201.
63. Xiaoying C, Huadan Y, Qingxiao H, Annan Z, Linlin T, Shiwei D. [The effects of DNA methylation on the homeostasis in vascular diseases]. [Article in Chinese]. Yi Chuan. 2015; 37:221-232.

64. Esteller M. Cancer epigenomics: DNA methylomes and histone-modification maps. Nat Rev Genet. 2007; 8:286-298.

65. Sharma S, Kelly TK, Jones PA. Epigenetics in cancer. Carcinogenesis. 2010; 31:27-36.

66. Hamamoto R, Furukawa Y, Morita M, Iimura Y, Silva FP, Li M, Yagyu R, Nakamura Y. SMYD3 encodes a histone methyltransferase involved in the proliferation of cancer cells. Nat Cell Biol. 2004; 6:731-740.

67. Fraga MF, Ballestar E, Villar-Garea A, Boix-Chornet M, Espada J, Schotta G, Bonaldi T, Haydon C, Ropero S, Petrie K, Iyer NG, Perez-Rosado A, Calvo E, et al. Loss of acetylation at Lys16 and trimethylation at Lys20 of histone $\mathrm{H} 4$ is a common hallmark of human cancer. Nat Genet. 2005; 37:391-400.

68. Vire E, Brenner C, Deplus R, Blanchon L, Fraga M, Didelot C, Morey L, Van Eynde A, Bernard D, Vanderwinden JM, Bollen M, Esteller M, Di Croce L, et al. The Polycomb group protein EZH2 directly controls DNA methylation. Nature. 2006; 439:871-874.

69. Kondo Y, Shen L, Suzuki S, Kurokawa T, Masuko K, Tanaka Y, Kato H, Mizuno Y, Yokoe M, Sugauchi F, Hirashima $\mathrm{N}$, Orito E, Osada H, et al. Alterations of DNA methylation and histone modifications contribute to gene silencing in hepatocellular carcinomas. Hepatol Res. 2007; 37:974-983.

70. Meng Y, Wang QG, Wang JX, Zhu ST, Jiao Y, Li P, Zhang ST. Epigenetic inactivation of the SFRP1 gene in esophageal squamous cell carcinoma. Dig Dis Sci. 2011; 56:3195-3203.

71. Garcia-Tobilla P, Solorzano SR, Salido-Guadarrama I, Gonzalez-Covarrubias V, Morales-Montor G, DiazOtanez CE, Rodriguez-Dorantes M. SFRP1 repression in prostate cancer is triggered by two different epigenetic mechanisms. Gene. 2016; 593:292-301.

72. Kawamoto K, Hirata H, Kikuno N, Tanaka Y, Nakagawa M, Dahiya R. DNA methylation and histone modifications cause silencing of Wnt antagonist gene in human renal cell carcinoma cell lines. Int J Cancer. 2008; 123:535-542.

73. Daugaard I, Kjeldsen TE, Hager H, Hansen LL, Wojdacz TK. The influence of DNA degradation in formalin-fixed, paraffinembedded (FFPE) tissue on locus-specific methylation assessment by MS-HRM. Exp Mol Pathol. 2015; 99:632-640.

74. Do H, Dobrovic A. Sequence artifacts in DNA from formalinfixed tissues: causes and strategies for minimization. Clin Chem. 2015; 61:64-71.

75. Shen S, Qu Y, Zhang J. [The application of next generation sequencing on epigenetic study]. [Article in Chinese]. Yi Chuan. 2014; 36:256-275.

76. Eads CA, Danenberg KD, Kawakami K, Saltz LB, Blake C, Shibata D, Danenberg PV, Laird PW. MethyLight: a highthroughput assay to measure DNA methylation. Nucleic Acids Res. 2000; 28:E32. 
77. Eisenhauer EA, Therasse P, Bogaerts J, Schwartz LH, Sargent D, Ford R, Dancey J, Arbuck S, Gwyther S, Mooney M, Rubinstein L, Shankar L, Dodd L, et al. New response evaluation criteria in solid tumours: revised RECIST guideline (version 1.1). Eur J Cancer. 2009; 45:228-247.
78. Chen X, Yang Y, Liu J, Li B, Xu Y, Li C, Xu Q, Liu G, Chen Y, Ying J, Duan S. NDRG4 hypermethylation is a potential biomarker for diagnosis and prognosis of gastric cancer in Chinese population. Oncotarget. 2017; 8:8105-8119. doi: 10.18632/oncotarget.14099. 